\title{
Building Literate Teachers to Improve Learning Processes in Elementary School
}

\author{
Ni Wayan Suniasih ${ }^{1}$, I Wayan Sujana ${ }^{2}$ I Ketut Adnyana Putra ${ }^{3}$ \\ \{niwayan.suniasih@undiksha.ac.id ${ }^{1}$, iwayan.sujana@undiksha.ac.id², \\ ketut.adnyana.putra@undiksha.ac.id $\left.{ }^{3}\right\}$ \\ ${ }^{1,2,3}$ Universitas Pendidikan Ganesha, Indonesia
}

\begin{abstract}
This study aims to improve the learning process in SD Negeri 7 Dalung, by building literate teachers. The subjects in this study were 17 teachers. This research type is a classroom action research with lesson study settings. Data collection techniques used in this study are non-test techniques in the form of observation using spread sheets regarding the learning process. Data obtained were analyzed using the quantitative descriptive techniques. The results of this study are, at the pre-cycle stage with the ability of the teacher to carry out the learning process using an average value of 77 , which increased to 84.1 and 89.4 in the first and second cycles respectively. From these results, it can be concluded that there was an increase in the learning process by building literate teachers at 7 Dalung Public Elementary School, North Kuta.
\end{abstract}

Keywords: literate, learning process.

\section{Introduction}

Quality learning in the classroom is dependent on the teacher's ability to initiate and design effective learning techniques that will motivate students. In order to get the best of education, students in class need pay adequate attention to the teacher so that the aim of learning could be easily achieved in an effective and efficient manner. One of the most productive ways of teaching is by including examples when educating students with relevant sources.

For instance, a teacher in school or class is likely is gain attention from students by using teaching materials and tools to illustrate certain topics .Teachers as a source of learning, are considered to have certain advantages compared to students, therefore, in the learning process they need to carry out outstanding educational motivating techniques, to guide, and clarify the teaching material being studied by students. Many teachers are admired by their students because of their intellectual ability to inculcate knowledge in class. According to Law No.19 ( in Mulyasa ${ }^{1}$ ) professional competence is the ability to master learning material in an in-depth

${ }^{1}$ Mulyasa. 2009. Menjadi Guru Profesional Menciptakan Pembelajaran Kreatif dan Menyenangkan. Bandung: Remaja Rosdakarya. 
and professional manner that makes it possible to guide participants meet the standard competence as specified by the Standard National Education .

In reality, if one fails to realize the role of the teacher and thinks of them as those that only read a book to students without proper explanation, in-depth mastery knowledge, or use of various educational, then they need a rethink.. Teachers tend to make use of various learning materials from print media to electronics devices. The literate teacher is an educationist tasked with educating, teaching, guiding, directing, and training students using various academic sources. They are poised to ensuring that students' perform well by evaluating their writing, reading, and thinking skills. This in line with Chotimah's ${ }^{2}$ research which states teachers are knowledge facilitators who transmit knowledge from learning source to participants (students). Law No. 14 of 2005 states that "Teachers and Lecturers are education professionals with the main task of educating, teaching, guiding, directing , training, judging and evaluating, and impacting education on kids at an early age through various education medium". While literacy according to $\mathrm{UNESCO}^{3}$ is the ability to read, write and count. Literacy is currently identified as a tool used to identify, understand, interpret, create, and communicate on a digital media, rich in information.

With the right implementation of academic learning sources and materials in schools such as computer, internet, and other digital and manual materials, students will be encouraged to learn with an increased desire, and motivation..

The Head teacher will ensure that the teachers are civilized, and be able to understand teachers by analyzing and obtaining information from various sources capable of building a strong relationship with the management, source and learn from varieties of educational materials, and later impact all that has been learnt on students. A couple of schools have low motivational and support, however, this research aims at improving the learning process by building literate teachers at Dalung 7 Elementary School North Kuta.

\section{Research Procedure}

This stage begins with a request for a UPT permit by the Disdikpora North Kuta District, Badung Regency which was then continued to Dalung 7 Public Elementary School. After permission is obtained, observations are made, followed by teacher data collection, and documentations.

${ }^{2}$ Chotimah, Yuyun Dwita Sari. 2008. Model-Model Pembelajaran Untuk PTK. Yayasan Pendidikan Universitas Negeri Malang: SMA Laboratorium UM

${ }^{3}$ UNESCO. 2017. Literacy. (online, tersedia pada http://en.unesco.org/themes/literacy-all, diterjemahkan dan diunduh pada 21 Oktober 2018) 
The implementation of this research is in the form of classroom action research with lesson study settings. The activity begins with the teacher getting acquinted with the students, giving guidance and assistance on the conduct of research. Implementing is followed in the form of classroom action research (CAR), which comprises of four cycle: planning, implementation, observation and reflection. In detail the activity is described as follows.

\subsection{Planning}

In planning, the activity begins with a discussion by the team which is then continued by conducting socialization activities and workshops aimed at making the learning implementation plan comprising of various learning resources related to building the literacy process that enhances the learning process.

\subsection{Implementation}

Implementation is carried out using the guidance techniques by providing theoretical debriefing to teachers capable of maximizing all components, and learning resources used during the learning process. After getting the theory from the team, the student who is the target subject is taught in accordance with the theories that have been obtained by the teacher. Implementation begins with the preparation of lesson plans inline with the needs of the 21 st century education strategy.

\subsection{Observations}

After gaining adequate knowledge and practice, teachers are given the ability to guide, and teach their students by applying the knowledge they have acquired during the mentoring process. Observations were also carried out by other teachers who acted as observers.

\subsection{Reflection}

Reflection finds out how effective learning activities are after being given assistance to become literate teachers. Reflection is done by providing constructive suggestions and criticism by the observation team, as well as colleagues

\section{Results and Discussion}

The implementation of this research activity, involving 17 teachers in Dalung 7 public elementary school as the subject of research has reached the target of applying literate teachers. The following are the results of research that has been carried outin two cycles. 
Based on the results of the research in Dalung 7 Public Elementary School, the value obtained at the pre-cycle stage, cycle I, and cycle II for each teacher observed by the teacher code is tabulated in table 1 below:

Tabel 1. Results of Research Data Analysis at Dalung 7 Elementary School

\begin{tabular}{|c|c|c|c|c|c|c|c|c|c|c|}
\hline \multirow{2}{*}{ No. } & \multirow{2}{*}{ Code } & \multicolumn{3}{|c|}{ pre-cycle } & \multicolumn{3}{|c|}{ Cycle I } & \multicolumn{3}{|c|}{ Cycle II } \\
\hline & & $\mathbf{L P}$ & Prc & $\bar{x}$ & RPP & Prc & $\bar{x}$ & RPP & Prc & $\bar{x}$ \\
\hline 1. & G.01 & 73 & 75 & 74 & 80 & 84 & 82 & 88 & 90 & 89 \\
\hline 2. & G.02 & 78 & 76 & 77 & 80 & 86 & 83 & 88 & 92 & 90 \\
\hline 3. & G.03 & 74 & 78 & 76 & 86 & 88 & 87 & 89 & 91 & 90 \\
\hline 4. & G.04 & 77 & 71 & 74 & 85 & 81 & 83 & 90 & 88 & 89 \\
\hline 5. & G.05 & 71 & 79 & 75 & 82 & 80 & 81 & 90 & 89 & 89.5 \\
\hline 6. & G.06 & 74 & 82 & 78 & 80 & 86 & 83 & 89 & 92 & 90.5 \\
\hline 7. & G.07 & 74 & 78 & 76 & 82 & 84 & 83 & 89 & 90 & 89.5 \\
\hline 8. & G.08 & 78 & 80 & 79 & 88 & 82 & 85 & 91 & 87 & 89 \\
\hline 9. & G.09 & 76 & 70 & 73 & 86 & 88 & 87 & 88 & 90 & 89 \\
\hline 10. & G.10 & 77 & 79 & 78 & 84 & 82 & 83 & 91 & 89 & 90 \\
\hline 11. & G.11 & 78 & 82 & 80 & 86 & 84 & 85 & 90 & 87 & 88.5 \\
\hline 12. & G.12 & 73 & 81 & 77 & 82 & 84 & 83 & 88 & 91 & 89.5 \\
\hline 13. & G.13 & 79 & 83 & 81 & 87 & 85 & 86 & 88 & 92 & 90 \\
\hline 14. & G.14 & 75 & 81 & 78 & 86 & 82 & 84 & 90 & 88 & 89 \\
\hline 15. & G.15 & 74 & 82 & 78 & 80 & 84 & 82 & 88 & 89 & 88.5 \\
\hline 16. & G.16 & 75 & 81 & 78 & 90 & 88 & 89 & 87 & 91 & 89 \\
\hline 17. & G.17 & 76 & 78 & 77 & 84 & 82 & 83 & 88 & 90 & 89 \\
\hline \multicolumn{2}{|r|}{ Total } & \multicolumn{3}{|c|}{1309} & \multicolumn{3}{|c|}{1429} & \multicolumn{3}{|c|}{1519} \\
\hline \multicolumn{2}{|c|}{ Average } & \multicolumn{3}{|c|}{77} & \multicolumn{3}{|c|}{84,1} & \multicolumn{3}{|c|}{89,4} \\
\hline \multicolumn{2}{|c|}{ Median } & \multicolumn{3}{|c|}{77} & \multicolumn{3}{|c|}{83} & \multicolumn{3}{|c|}{89} \\
\hline \multicolumn{2}{|r|}{ Mode } & \multicolumn{3}{|c|}{78} & \multicolumn{3}{|c|}{83} & \multicolumn{3}{|c|}{89} \\
\hline
\end{tabular}

*Information: LP = Lesson Plan, Prc = Practice

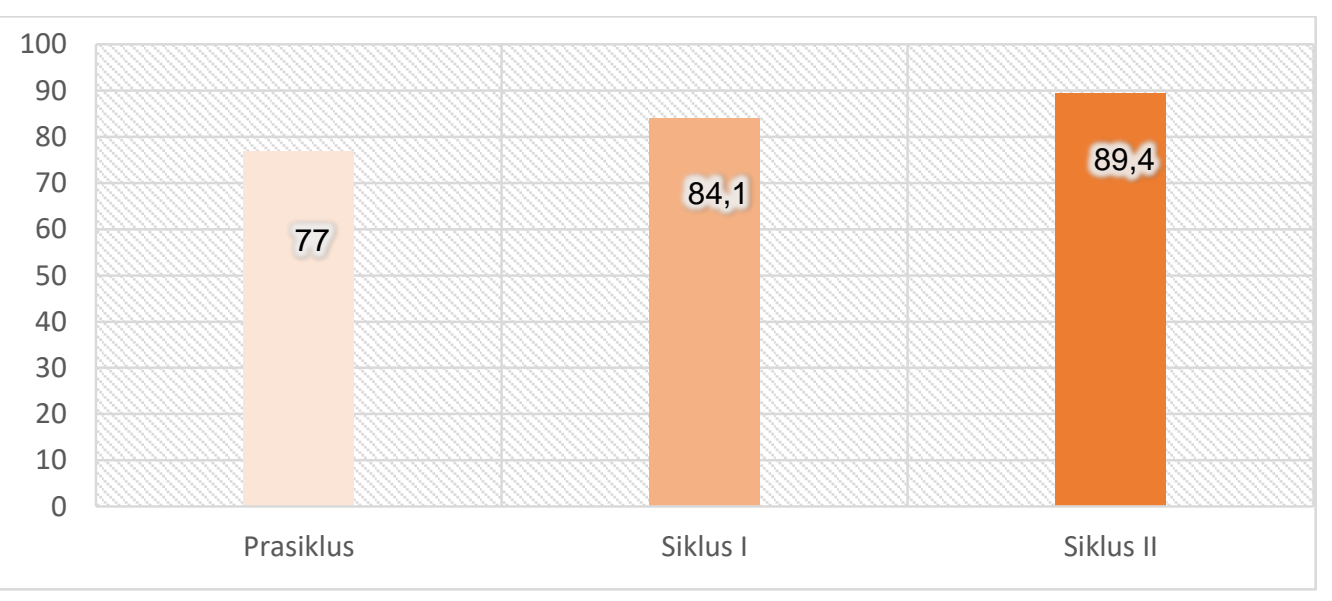

fig. 1. Chart of average research results 
From the results of the analysis, the results obtained in the first cycle were the average teacher's ability in the high category with qualification B. In this first cycle several problems were encountered, namely the teacher's inability in familiarizing students with the various learning materials. Students are still conventionally utilizing textbooks, although there are some older students who have started to make use of other sources of information. In this first cycle, 12 teachers were in the medium category with a value of $\mathrm{B}$, with only 5 of them in the high level qualification of $\mathrm{A}$.

In the second cycle, there was an increase with an average of 89.4. The inconsistecies inherent the former was overcome with constructive suggestions and criticism by all colleagues and the research team in this cycle. All the teachers were in very high criteria with a qualification of A. This indicates that they were very enthusiastic and really implemented all the lessons learned in the mentoring activities.

The results of this research are based on Siyamitri [4] with the results of TKJ teachers being able to implement internet media literacy in carrying out their duties. It can be practiced on an elementary school teacher for an environment enrich student learning resources with news that is always new. Rohman [5] which explains that every child has language skills, and to maximize the potential of language and reading it requires the active role of various parties from school to community (people society).

\section{Conclusion}

From the analysis and discussion, it can be concluded that there is an increase in the quality of learning through efforts to build literate teachers at Dalung 7 North Kuta Elementary School.

\section{Reference}

[1] Mulyasa.: Menjadi Guru Profesional Menciptakan Pembelajaran Kreatif dan Menyenangkan. Bandung: Remaja Rosdakarya. (2009)

[2] Chotimah, Yuyun Dwita Sari.: Model-Model Pembelajaran Untuk PTK. Yayasan Pendidikan Universitas Negeri Malang: SMA Laboratorium UM (2008)

[3] UNESCO. 2017. Literacy. (online, tersedia pada http://en.unesco.org/themes/literacyall, diterjemahkan dan diunduh pada 21 Oktober 2018)

[4] Siyamitri, Puty.: Literasi Media Internet pada Kalangan Guru Sekolah Menengah Kejuruan di Kota Medan. Universitas Sumatra Utara: Jurnal Simbolika/Volume 1/Nomor 2/September 2015. ISSN 2442-9198 (2015)

[5] Rohman,Syaifur. 2016. Membangun Budaya Membaca Pada Anak Melalui Program Gerakan Literasi Sekolah. INSTITUT ILMU KEISLAMAN ZAINAL HASAN: Jurnal Pendidikan dan Pembelajaran Dasar. Volume 4 Nomor 1 Juni 2017. ISSN 2355-1925

[6] Suciani, Ni Made. 2017. Menjadi Guru Literat. Denpasar: Makalah senimar, disajikan pada Seminar dan Workshop Implementasi Pennguatan dan Pendidikan karakter (PPK) 
dan Gerakan Literasi Sekolah (GLS) di Kampus Undiksha UPP II Denpasar, pada Sabtu 16 Desember 2017

[7] Undang-Undang Nomor 14 Tahun 2005 tentang Guru dan Dosen. 